\title{
THE PIPING PLOVER \\ IN SASKATCHEWAN: \\ A STATUS REPORT
}

WAYNE E. RENAUD, LGL Ltd. - environmental research associates, 4 Eglinton Ave. West, Toronto, Ontario M4R 1A1, GUY J. WAPPLE, Box 1153 Biggar, Saskatchewan SOK OMO, and DURAND W. EDGETT, 628 Church St. Apt. 4, Toronto, Ontario M4Y 2 G3.

The Piping Plover is the only small plover that breeds in a large area of southern Canada and the northern United States. Its breeding range is divided, probably by habitat availability, into three areas: the Atlantic coast from Virginia to Newfoundland, the Great Lakes, and the western plains from central Alberta and Manitoba to Nebraska. ${ }^{2}$ The Piping Plover nests in a variety of habitats including ocean beaches, sand dunes, river bars, and the shores of lakes, alkaline sloughs and reservoirs.

During the past 100 years, the Piping Plover has experienced population declines over a large portion of its range. In the late 1800's, spring hunting in New England greatly reduced the numbers of Piping Plovers breeding along the Atlantic coast. 11 This practice had largely ceased by the early 1900's, and their numbers slowly increased. The effect of spring hunting on the western population is not known, but was probably small, since most Great Plains breeders apparently migrate through the Central Flyway from wintering areas along the Gulf Coast. 32 In the New England States, the Canadian Maritimes and along the Great Lakes, a second decline became evident by the 1960's and 1970's. The Piping Plover has been included on the National Audubon
Society's "Blue List" of threatene species since its inception in 1972.3-

This paper briefly summarizes th species' status in Canada, an brings together all existing infor mation on its occurrence in Saskat chewan.

\section{Status in Canada}

Declines since the 1930's hav been most severe along the Grea Lakes. In the late 1800's and earl 1900 's, Piping Plovers nested alon the Canadian shorelines fron Kingston to the Bruce Peninsula.2 The largest breeding population wa apparently at Long Point, a $29-\mathrm{km}$ long peninsula on the north shore 0 Lake Erie. Snyder estimated that a least 100 pairs nested there in 1930 and Sheppard counted up to 5 adults in one day during Jul 1935.4039 Numbers at Long Poin declined during the 1960's anc 1970's.1526 In 1977 only one pai nested (Gary Miller, pers. comm.) and in 1978 no nests were foun during systematic surveys by Lons Point Bird Observatory personne (Ann Lambert and Erica Nol, pers comm.). Long Point was the las location along the Great Lake where Piping Plovers were known to have nested. In the adjacent Uniter States, small numbers still nest alons the Great Lakes in Minnesota,23 4 Wisconsin, 43 and Michigan. ${ }^{33}$ 
Declines in the Canadian Great akes population have been generally attributed to summer cotage development and recreation. 16 However, at Long Point human disturbance is confined to a small area even during the summer. Bradstreet et al. and Gary Miller (pers. comm.) suggest that rising lake evels and associated habitat destruction may, in part, account for he observed decline.12 Another bossible factor is greater predation from a four-fold increase in the humbers of summering gulls 26 Michael Bradstreet and Chip Weseloh, pers. comm.).

In the Maritime Provinces, Piping lovers are still common on a few solated beaches. In 1975 and 1976 , Cairns studied a population of 27 to 29 pairs on a $1.6-\mathrm{km}$-long spit in southern Nova Scotia.13 However, the total population of Newfoundland, Nova Scotia, Prince Edward sland, the Magdalen Islands, and eastern Quebec is thought to number only 300 to 350 breeding pairs (Winifred Cairns and Ian McLaren, pers. comm.). None now nest on the north shore of the Gulf of St. Lawrence Cairns and McLaren, pers. comm.) r on the Gaspe Peninsula (D. David n Arbib 1976). The species also no onger nests on Sable Island where Macoun and Macoun found them common at the turn of the century.1329 The decline along the Atlantic coast is believed to be the result of many factors including 1) recreational disturbance on beaches, 2) greater predation by several species of animals, including gulls, crows, foxes and racoons all of which have increased as result of human influence, and 3) fluctuations in the amount of beach habitat available due to instability of the dynamic dune and barrier beach systems (Cairns and McLaren, pers. comm.).
The Great Plains population is the least known, although its approximate range has been welldefined for several decades.2 1937 No published population estimates are available for Manitoba, Saskatchewan or Alberta. In Manitoba, Piping Plovers nest most regularly on the extensive sandy beaches and islands of Lakes Manitoba, Winnipeg and Winnipegosis and at Shoal Lake east of Woodlands (Herb Copland, pers. comm.). In Alberta, Piping Plovers have been recorded nesting on eight lakes28; population estimates are available only for Dowling Lake, which was completely censused in 1977 by Chip Weseloh (pers. comm., report in prep.).

In Saskatchewan, little quantitative information has been published since Piping Plovers were first reported at Deep Lake near Indian Head in 1892.29 Up to 1973 , nesting had been suspected or verified at 20 localities ${ }^{34}$, but until 1978 no population estimates were available for any of these locations.

\section{A Survey of the Quill Lakes}

In June 1978, we undertook a survey of part of the Quill Lakes $\left(51^{\circ} 53^{\prime} \mathrm{N}, 104^{\circ} 15^{\prime} \mathrm{W}\right)$ in south-central Saskatchewan. This area was chosen for two reasons: 1) it contains one of the largest, if not the largest, breeding populations of Piping Plovers in the province, and 2) some quantitative information on the species' status is available for 1909.17 While on a collecting expedition for the Field Museum of Natural History in Chicago, John F. Ferry spent 9 June to 11 August 1909 exploring the Quill Lakes. He listed the Piping Plover as "common" and "distributed along the south shore of [Big] Quill Lake in the proportion of about one pair of birds to the mile." 


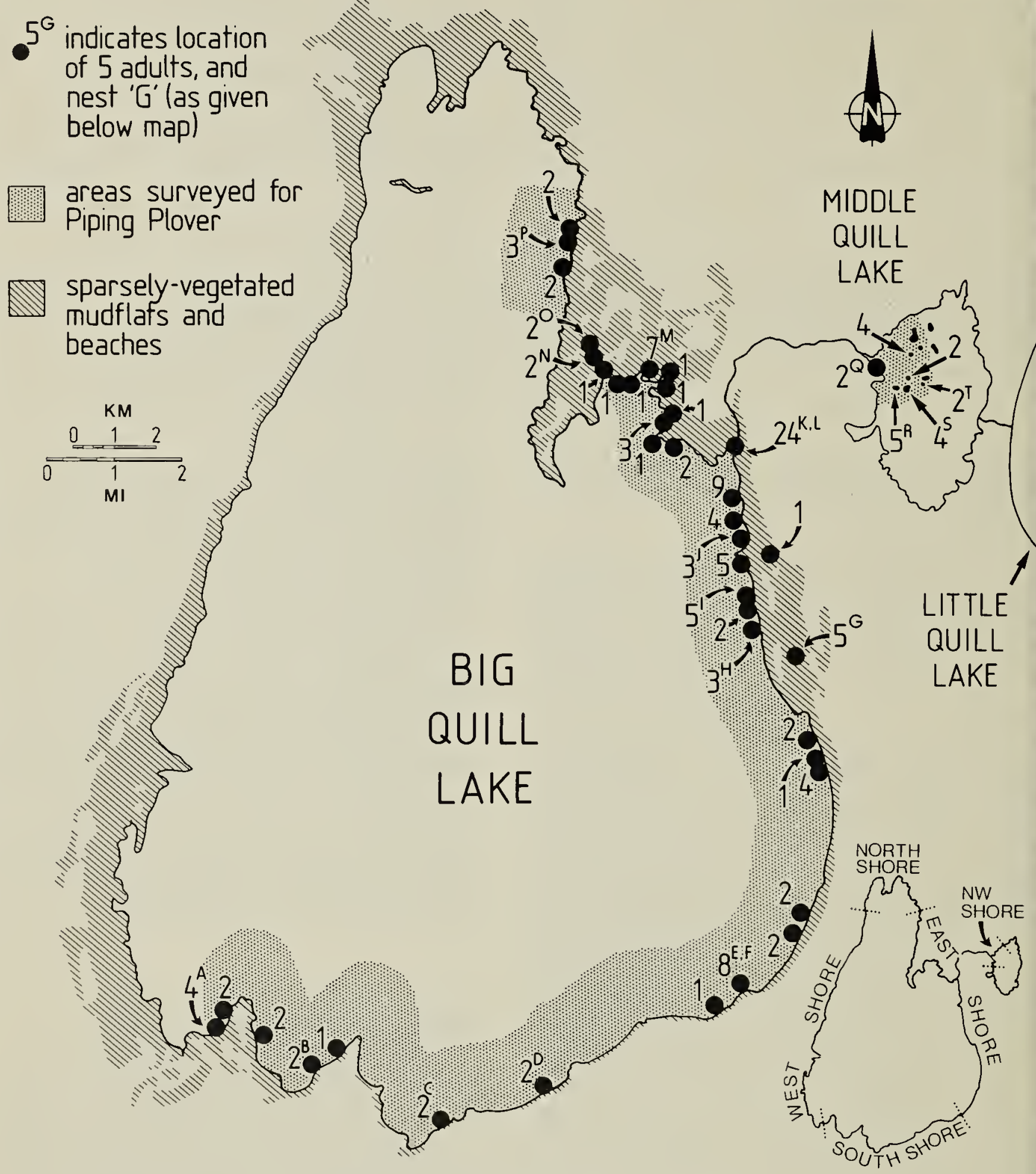

NESTS AND BROODS ( $N=$ nest, $B=$ brood, $e=e g g, y=y o u n g$ )
A-B1y
E - B1y
I- B1y
M- B4y
Q-N5e
B - B1y
F - B2y
C-B1y
G-N4e
J - B1y
$\mathrm{N}-\mathrm{B} 2 \mathrm{y}$
$\mathrm{R}-\mathrm{N} 1 \mathrm{e}, 2 \mathrm{y}$
D-B2y
$\mathrm{H}-\mathrm{N} 4 \mathrm{e}$
K- B1y
O-N4e
$\mathrm{S}-\mathrm{N} 3 \mathrm{e}$
$L-B 3 y$
$\mathrm{P}-\mathrm{N} 4 \mathrm{E}$
$\mathrm{T}$ - N1e

Figure 1: Distribution of Piping Plover adults, broods and nests at the Quill Lakes, Saskatchewan, June 19-21, 1978.

METHODS: On 19, 20 and 21 June 1978 we walked $2.9 \mathrm{~km}(1.8 \mathrm{mi})$ of shoreline and, in addition, surveyed 8 islands in Middle Quill Lake, and walked $40.5 \mathrm{~km}(25.3 \mathrm{mi})$ of shoreline along Big Quill Lake (Fig. 1). 
Shoreline positions were mapped and lengths were measured from aerial photographs taken in 1966* when levels appeared to be similar to 1978. One or two observers on foot followed the shoreline, and stopped at intervals to listen and scan with binoculars. In some areas where unvegetated mudflats extended for more than $1 / 2 \mathrm{~km}$ from the shoreline ve made attempts to survey adjacent areas, hence the observations of some plovers up to $800 \mathrm{~m}$ from the shoreline proper. However, because bf time constraints most of our time was spent surveying the area immediately adjacent to the shoreline, and some adults were probably nissed. Since our main objective was to determine the size of the adult population, minimal time was spent ooking for nests and broods and nany of these were undoubtedly nissed.

RESULTS: The numbers of adults, roods and nests located are given n Figure 1; the numbers of adults are ummarized in Table 1. Notes on ther species appear in the Appenfix.

We observed 145 adults, 8 nests ind 12 broods. Adult densities veraged 1.3 per linear $\mathrm{km}(2.1 / \mathrm{lin}$ i) of shoreline along the south hore, and 4.6 per lin $\mathrm{km}$ (7.4/lin $\mathrm{mi})$ long the east shore of Big Quill ake (see Fig. 1 for shoreline esignations). Most of the 19 Piping lovers observed at Middle Quill ake were on islands; the density long the northwest lakeshore was .7 per lin $\mathrm{km}(1.1 / \mathrm{lin} \mathrm{mi})$.

Most Piping Plovers were seen ingly or in pairs; usually where more han two were seen in the same area, pere was much calling and

Photos A19678:66-73, 168-174, 251; 1:57,000 scale, National Air Photo Library, Ottawa. displaying. Nothing that appeared to be a non-breeding flock was observed. The largest group consisted of six adults and three chicks (Fig. 1 brood ' $L$ '). All other broods were accompanied by one or two adults. Most chicks were estimated to have been from 7 to 10 days old.

DISCUSSION: The density of Piping Plovers along the south shore of Big Quill Lake in 1978 was about one pair per mile of shoreline, similar to that reported by Ferry in 1909. Ferry's figure was an approximation, not an actual census, but we can probably conclude that no great change in numbers has occurred along the south shore during the past 69 years.

The water level of the Quill Lakes has dropped substantially since 1909 (see Wynyard 72P/16 map sheet; 1:50,000 scale for shoreline fluctuations); probably the greatest change since that time occurred during the drought of the 1930's. This drop in water level appears to have had little effect on the position of the south shore which has a relatively steep shoreline gradient. However, along most other shorelines on Big Quill Lake, the land/water interface has retreated from 1 to $5 \mathrm{~km}$, exposing large, sparsely-vegetated, alkaline flats. Possibly, the newlyexposed mudflats now provide more favourable Piping Plover habitat than was present in 1909 when the lake was higher and less alkaline. The marked variability in habitat now existing on Big Quill Lake probably accounts for the different densities of Piping Plover found along the south vs east shore.

In an attempt to estimate numbers of Piping Plovers at Big Quill Lake, we mapped sparsely-vegetated habitats from 1966 aerial photographs. The extent of sparselyvegetated areas along the north and west shores was similar to that along 


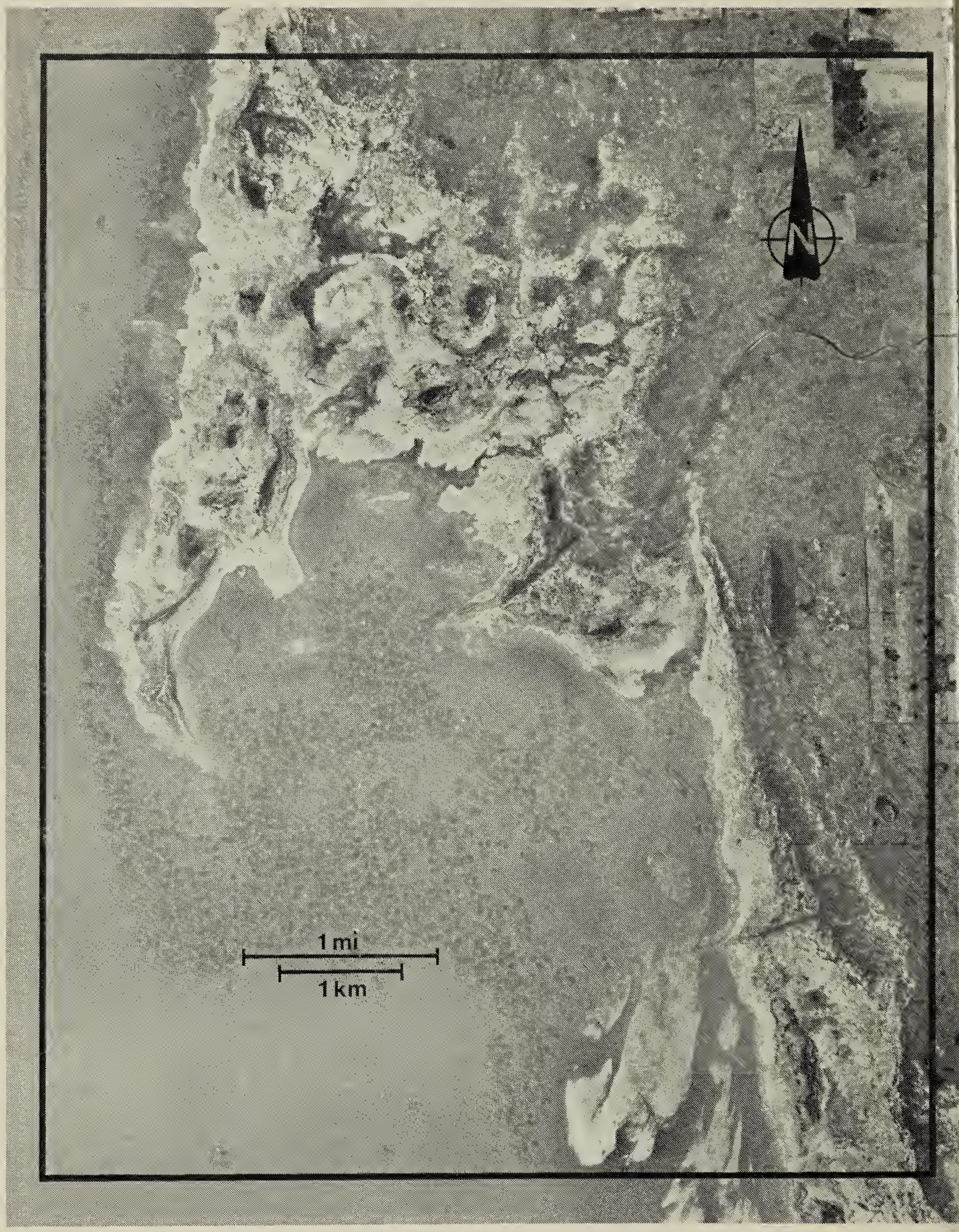

Aerial photograph of the east shore of Big Quill Lake, 1966. The poorly-vegetated alkaline flats where Piping Plovers were most numerous in 1978, appear white or ligh grey on the photograph.

(Photo A19678-68, National Air Photo Library, Ottawa.

the surveyed east shore; hence our density for the east side was extrapolated to these other areas of Big Quill Lake. An estimate of 337 adults was obtained (Table 1). This estimate excludes any that may nest on the large island near the north end of Big Quill Lake or any missed because our surveys concentrated on the shoreline interface. 
TABLE 1. Densities and population estimates of adult Piping Plovers at Big Quill and Middle Quill Lakes, June 1978.

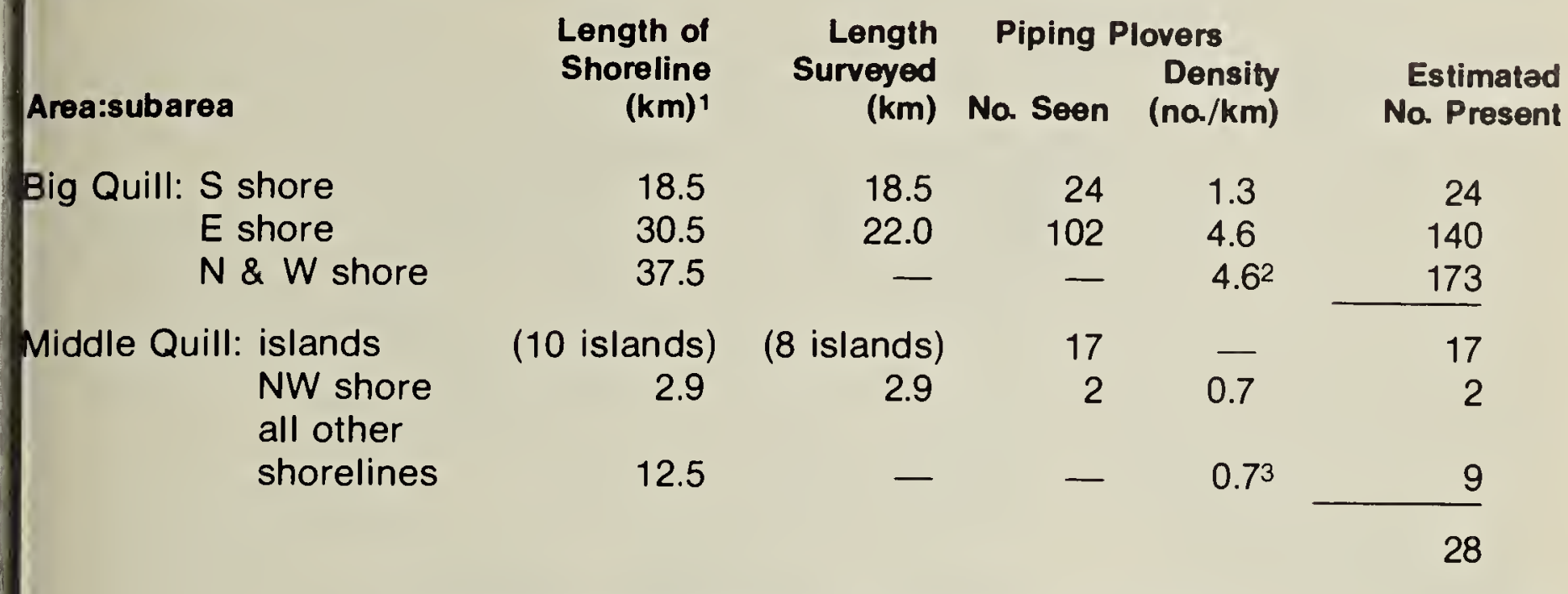

Total estimate (Big Quill + Middle Quill Lakes)

1A linear kilometer (lin $\mathrm{km}$ ) as referred to here, and in the text, is the length of the shoreline including major indentations.

2Extrapolated from density along $E$ shore; see text.

${ }^{3}$ Extrapolated from density along NW shore; 'see text.

Based on similar procedures, the population of Middle Quill Lake was estimated as 28 adults (19 were actually observed). It seems probable that few, if any, nested on the two small gull nesting islands that we failed to visit.

No survey was conducted on Little Quill Lake in 1978. Aerial photographs indicate that the shoreline is much better vegetated and more abrupt with few beaches or alkaline flats. Renaud saw no Piping Plovers along the south shore, an area largely overgrown with foxtail, during July 1973; and Bob Godwin (pers. comm.) saw none along the lakeshore during CWS banding activities in July 1977. In fact, to our knowledge there have been no observations of Piping Plovers at Little Quill Lake. Probably few, if any, nest there.

Hence, we estimate that a population of 350 to 400 adults inhabited the Quill Lakes in 1978. A survey of the north and west shore of
Big Quill Lake would verify whether densities in these areas are as high as suspected.

\section{The Status of the Piping Plover In Saskatchewan}

The Piping Plover is a rare transient in southern Saskatchewan in areas away from the breeding sites; most records consist of single individuals seen alone or in flocks with other small shorebirds. Macoun and Macoun found Piping Plovers "common" in migration at Deep Lake (a breeding locality) in late May 1892 but no more recent spring concentratons have been observed.29 The largest "fall" group, consisting of 43 adults (probably a post-breeding or non-breeding flock), was recorded at Middle Quill Lake on 5 July 1972.34 Five individuals at Porter Lake east of Saskatoon on 10 July 1971 was the largest group recorded at a nonbreeding locality. ${ }^{21}$

Principal dates of occurrence in the province are early May to mid- 


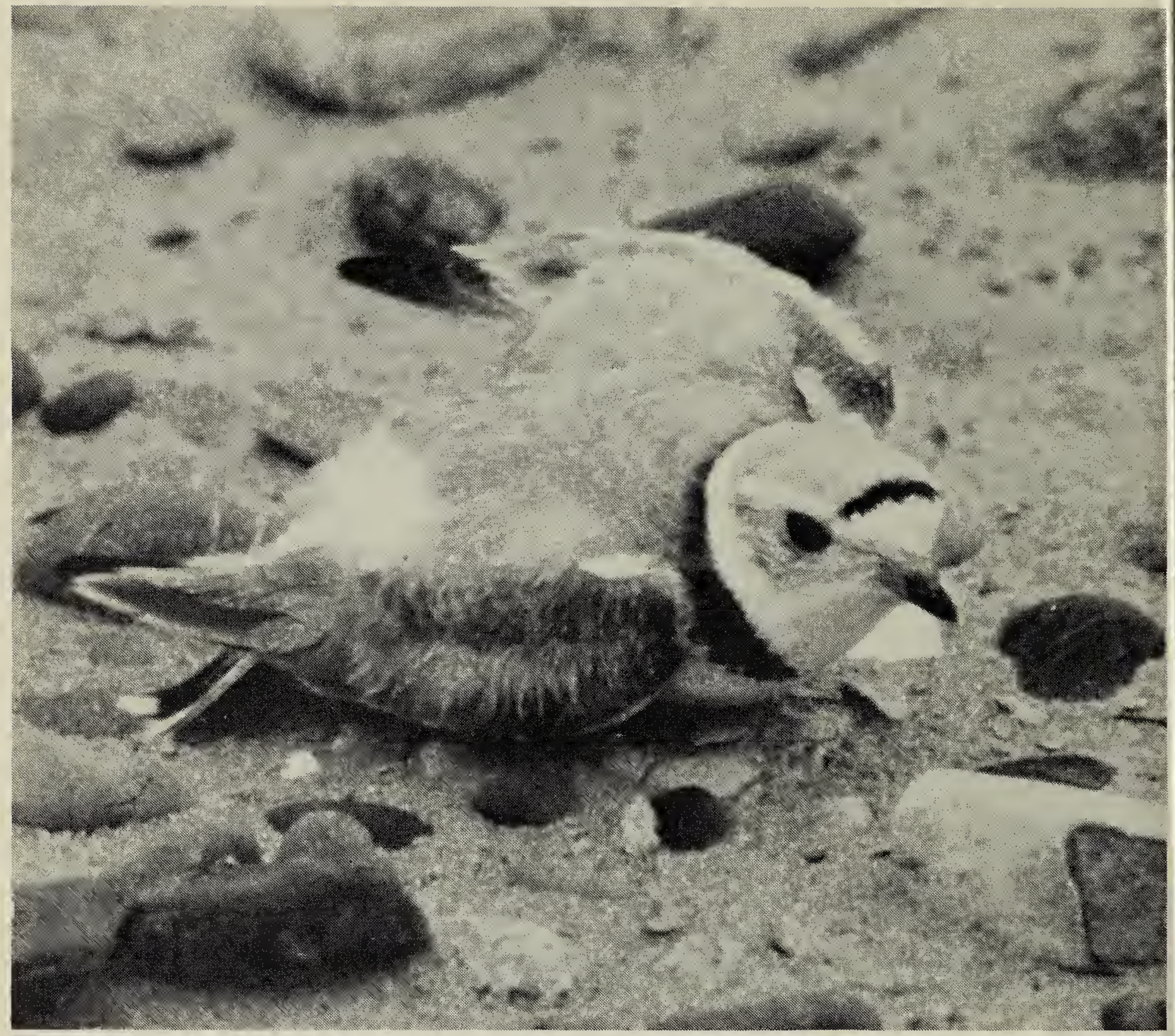

Adult Piping Plover feigning a broken wing, Cavendish sandspit, Nova Scotia. Winnifred Cairns

August, and extremes are 22 Apri|35 and 1 October. 9 Dates of 43 nests ranged from 23 May to 14 July (both extremes with 4 eggs and tending adults). ${ }^{34}$ The peak of incubation appears to be from late May to midJune. The dates of 24 flightless broods ranged from 19 June (this paper) to 10 August.22 Some of the young seen on 19 June 1978 were estimated to have been at least 10 days old, suggesting that full clutches may be expected as early as the 3rd week of May and young by the 2nd week of June. The young observed on 10 August 1967 were downy; probably flightless young occur in some years until the 3rd week of August.
Renaud summarized the Saskatchewan breeding records up to 1973; seventeen additional breeding areas have been identified, no doubt a result of more thorough coverage of potential habitat rather than an increase in numbers. ${ }^{34}$ All records through 1978 are given in Fig. 2 and Table 2.

Although observations at most breeding localities in Saskatchewan have been far from systematic, there is some evidence that populations may shift unpredictably from year to year. In the Sarnia Beach area of Last Mountain Lake, Piping Plovers were "very common breeders" in 1975, but were entirely absent in the same area during investigations in 1976 and 


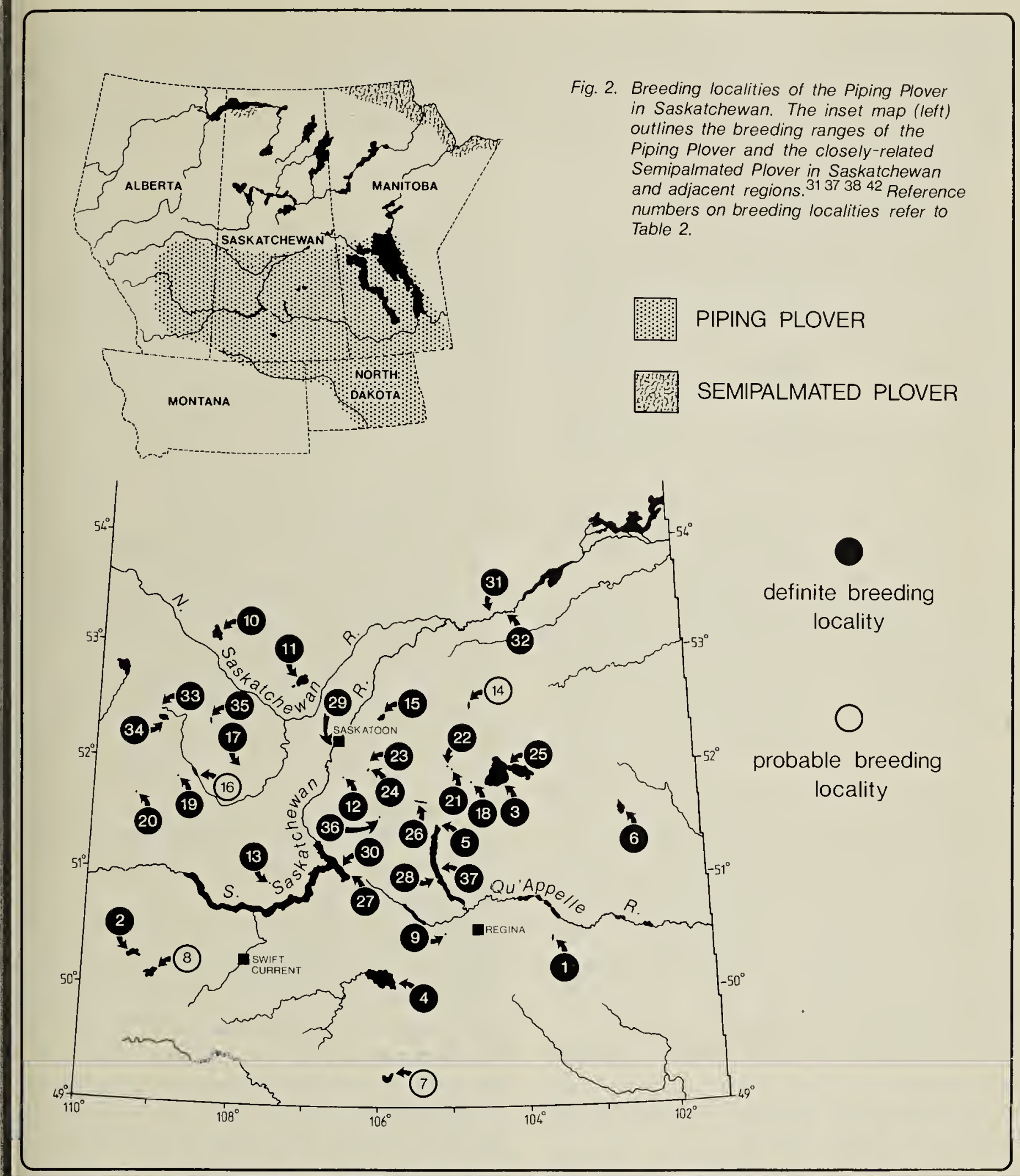

197824 (David Hatch, pers. comm.). In all three years (1975, 1976 and 1978), Hatch considered Piping Plovers present in "good number" at the north end of Last Mountain Lake, and the species nested on the east side of the lake NE of Sarnia Beach in 1978 (Dale Hjertaas, pers. comm.). An unnamed lake $23 \mathrm{~km}$ SE of Biggar was used by a pair of Piping Plovers during only two years (1972 and
1978) from 1968 to 1978 although the lake contained some water during May and June each year (Renaud, pers. obs.).

At other localities, the Piping Plover may be a regular breeder. C. Stuart Houston (pers. comm.) observed Piping Plovers annually on the islands in Redberry Lake during birdbanding trips from 1964 to 1978. At Big Quill Lake, Piping Plovers were 
TABLE 2. List of breeding localities of the Piping Plover in Saskatchewan. Records are mapped in Figure 2. Breeding records previously summarized in Renaud (1974) are listed here, but refer to the original source for full details. [Asterisks $\left({ }^{*}\right)$ denote new breeding localities; question marks (?) denote probable but not definitely proven breeding localities; PNRS $=$ Prairie Nest Records Scheme, $\mathrm{N}=$ nest, $\mathrm{e}=$ egg, $\mathrm{yng}=$ young; $w k=$ week $]$.

1. DEEP LAKE. Nest, 1892.29

2. BIG STICK LAKE. Brood, 1906.10

3. BIG QUILL LAKE. Nest, broods, 1909.17 Renaud (1974) overlooked a record by Todd who collected 2 yng $6 \mathrm{~km}$ E of Dafoe on June $20 / 47$ and stated that Piping Plovers were "common".44 See also this paper.

4. OLD WIVES LAKE (= LAKE JOHNSTONE). Breeding. 30 Probably breeding, 1969.45

5. N END OF LAST MOUNTAIN LAKE. Nest, brood, 1932.44 Probably breeding, 1969.1 N5e, June 12/75; brood of $3 \mathrm{yng}$, July 11/75 (Cliff Matthews, Canadian Wildlife Service-PNRS). Brood of $2 \mathrm{yng}$, small island off Perry's Point, July 21/78 (J. R. Caldwell and C. Jorgenson fide J. B. Gollop). "Good numbers breeding in 1976, 1977 and 1978" (David Hatch, pers. comm.).

6. GOOD SPIRIT LAKE. Nesting, $1936 .{ }^{8}$ Disappeared as a breeder in 1950's (W. J. Anaka, pers. comm.).

7. FIFE LAKE? 2 adults seen, June 1940.41

8. CRANE LAKE? 3 adults seen, June 1948.

9. STONY BEACH LAKE. Nest, 1959 (Belcher 1961, PNRS).

10. JACKFISH LAKE. Nest, 1963.34

11. REDBERRY LAKE. 30 yng banded, 1964-1973.34

12. STREHLOW POND, $11 \mathrm{KM} \mathrm{N}$ OF DUNDURN. Nest, 1966.20

13. UNNAMED WATERBODY NEAR CLEARWATER LAKE. Brood, 1967.22

14. RANCH LAKE? Probably breeding, 1972. ${ }^{14}$

15. BUFFER LAKE. Nest, 1972.34

16. OPUNTIA LAKE. Adult feigning broken wing, 1972.34

17. UNNAMED LAKE, $27 \mathrm{KM}$ SE OF BIGGAR. Nest, 1972.34 N4e, June 18/78 (Renaud, pers. obs.).

18. "JANSEN. 4+ family groups, all with yng capable of flight, July 24-25/72 (David Hatch, pers. comm.).

19. *UNNAMED WATERBODY, $2.5 \mathrm{KM}$ NW OF DODSLAND. Pair with $2+$ yng, less than 1 wk. old, on dry slough bottom, July
14/72 (David Hatch, pers. comm.).

20. "UNNAMED WATERBODY, $8 \mathrm{KM} \mathrm{N}$, $1.5 \mathrm{KM}$ E OF SMILEY. N4e, 2 other pairs with broods, July 14/72 (David Hatch, pers. comm.).

21. "UNNAMED WATERBODY, 6.5 KM NE OF LANIGAN. Pair with a newly-fledged brood, July 20-21/72 (David Hatch, pers. comm.).

22. "ATTICA. Pair with 4 yng, July $21 / 72$ (David Hatch, pers. comm.).

23. UNNAMED WATERBODY, $8 \mathrm{KM} \mathrm{N}$ OF BRADWELL (AT BLUCHER). Nest, 1973.34 2.4. BRADWELL RESERVOIR. Nest, 1973.34 25. MIDDLE QUILL LAKE (= MUD LAKE). Nest, 1973.34 See also this paper.

26. "LITTLE MANITOU LAKE, NEAR WATROUS. Nesting was noted in 1974, 1976 and 1978. At least 22 pairs and 8 nests ( 7 with $4 \mathrm{e} ; 1$ with $3 e+1$ yng), June 29/78 (David Hatch, pers. comm.).

27. "AIKTOW, LAKE DIEFENBAKER. Two nests, each with $4 \mathrm{e}, 1 \mathrm{~km}$ apart, June $16 / 74.36$

28. "SARNIA BEACH, LAST MOUNTAIN LAKE. "Very common nesting species in 1975 with one island containing 4 nests (July 1)"24; none nested in any of these areas during investigations in 1976 and 1978 (David Hatch, pers. comm.).

29. " SOUTH SASKATCHEWAN RIVER AT SASKATOON. N4e on sand bar in river 1.5 km S of Queen Elizabeth Power Station, June 6/75 (Bob Godwin, pers. comm.).

30. "DOUGLAS PROVINCIAL PARK, LAKE DIEFENBAKER. N4e, on a cobble beach, June 11/75 (Gary Anweiler, pers. comm.). N4e, June 8/77 (Sheila Lamont, pers. comm.).

31. "SASKATCHEWAN RIVER, 2 KM W OF GRONLID FERRY. N4e on rocky beach of island, June 20/76 (Bob Godwin, pers. comm.).

32. "SASKATCHEWAN RIVER, $14 \mathrm{KM} \mathrm{E}$ OF GRONLID FERRY. Pair with 3 yng on sandbar, June 22/76 (Bob Godwin, pers. comm.).

33. "KILLSQUAW LAKE. 4 adults with 2 yng ( 3 days old), June 25/78 (Renaud, 
pers. obs.).

34. "MUDDY LAKE, S OF UNITY. Pair with 3 yng (2 wks. old), June 25/78 (Renaud, pers. obs.).

35. "AROMA LAKE. 23 adults with 6 yng (2 wks. old), June 25/78 (Renaud, pers. obs.). 36. "UNNAMED WATERBODY, $22.5 \mathrm{KM} \mathrm{E}$ OF KENASTON. 2 nests, each with $4 \mathrm{e}$, June 20/78 (David Hatch, pers. comm.).

37. *LAST MOUNTAIN LAKE (S18-T24R23-W2M). N4e, 2 pairs present, June 17/78 (Dale Hjertaas \& Paule Brochu, pers. comm.).

considered common in 190917 , 194744 , and 1978 (this paper), the only years when the shoreline avifauna was assessed in detail.

Unlike Piping Plovers along the Atlantic coast and in the Great Lake region, the majority of the Piping Plovers in Saskatchewan nest on alkaline and salt lakes, most of which have received little human disturbance. However, on fresh-water lakes and some deep salt lakes where provincial and regional parks are located (e.g., Jackfish Lake, Redberry Lake, Little Manitou Lake), the species will become increasingly threatened by recreational activities. Those plovers nesting at Diefenbaker Lake and on sandbars in the Saskatchewan Rivers are subject to sudden changes in water levels during incubation, due to sudden releases of water from Gardiner Dam. For Piping Plovers that nest on small alkaline lakes, periodic drought may be the most important factor presently limiting numbers. In spite of these seemingly detrimental influences, the Piping Plover has shown its ability to colonize man-made habitats (e.g., Bradwell Reservoir, Diefenbaker Lake, probably Opuntia Lake).

There appears to be no definite indication that the numbers of Piping Plovers in Saskatchewan have declined drastically during recent decades. The Quill Lakes population is likely at least as numerous as it was in 1909. The fact that 22 of the 33 known breeding localities (Table 2) were discovered since 1970 indicates that the species is still widely distributed in southern Saskatchewan. Of the six localities identified as breeding sites prior to 1950 , only two areas are thought to have been abandoned: Big Stick Lake due to drought 18 and Good Spirit Lake due to high water levels (William J. Anaka, pers. comm.). The species still breeds at Big Quill Lake, Last Mountain Lake and Old Wives Lake. Its present status at Deep Lake is unknown.

While it is still impossible to accurately estimate the Piping Plover population of Saskatchewan, it appears to be substantial and, with the possible exception of Manitoba, Saskatchewan may contain the largest number of any province in Canada. It seems probable, in view of the hundreds of kilometers of shoreline habitat available on as yet uncensused alkaline and salt lakes in Saskatchewan, that the Quill Lakes support less than a third of the total provincial population. A population of 1,000 to 1,500 adults, some portion of which are likely nonbreeders, may be a reasonable estimate. More extensive surveys of prime habitat could provide a more reliable population estimate for this unique member of our prairie avifauna.

\section{Summary}

During a survey of parts of Big Quill and Middle Quill Lakes on 19-21 June 1978, 145 adult Piping Plovers were recorded; an estimated 350 to 400 adults inhabitated the area. A density of approximately one pair per linear mi of shoreline was observed along the south shore of Big Quill Lake in 1978; a similar density was reported here in 1909. Numbers of 


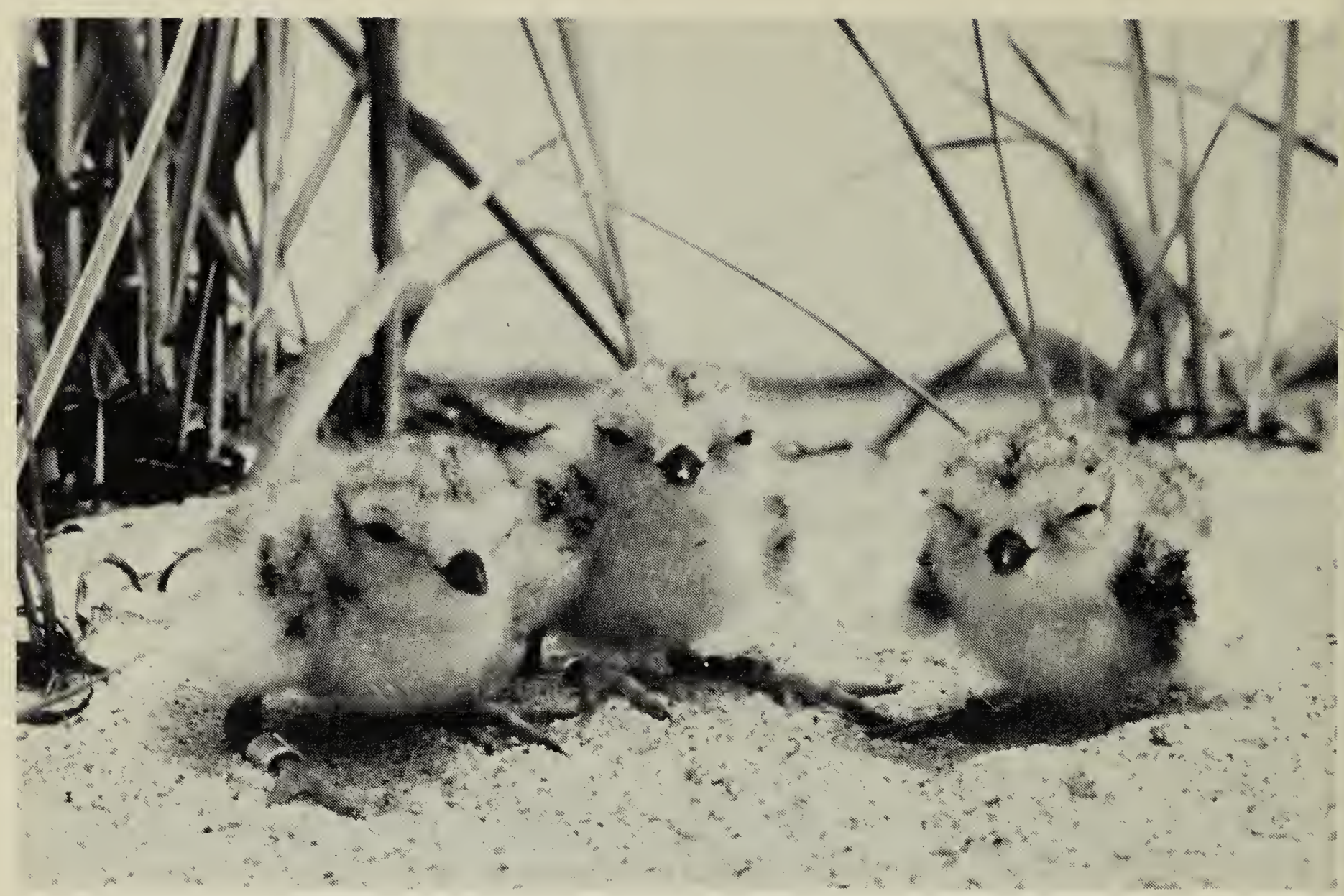

Piping Plover chicks about one day old, Cadden, Queens County, Nova Scotia. Note the egg tooth on the bill of the middle chick.

Winnifred Cairns

Piping Plovers at the Quill Lakes have probably not declined during the intervening 69 years.

Extreme dates of occurrence in Saskatchewan are 22 April and 1 October; usually present from early May to mid-August. Egg dates range from 23 May to 14 July. Flightless young may be present from the 2 nd week of June until the 3rd week of August.

Breeding habitats include river bars and the shorelines of alkaline lakes, freshwater lakes and manmade reservoirs. There is no evidence that Piping Plovers have declined province-wide in this century, but factors such as increased recreational activities on freshwater and some deep salt lakes, rising water levels on major rivers and on Diefenbaker Lake during the breeding season, and drought on small, alkaline lakes probably limit populations in some areas. Populations may shift unpredictably in some areas from year to year (e.g., Sarnia Beach, Last Mountain Lake). The future security of the Saskatchewan population lies in its extensive utilization of large, undisturbed salt and alkaline lakeshores.

\section{Acknowledgements}

The following persons have contributed unpublished breeding records: Gary Anweiler, Paule Brochu, Bob C. Godwin, J. Bernard Gollop (Prairie Nest Records Scheme), David R. M. Hatch, Dale Hjertaas and Sheila M. Lamont. Numerous persons commented on the manuscript: Michael S. W. Bradstreet, Winnifred Cairns, Wayne C. Harris, David R. M. Hatch, C. Stuart Houston, Ann Lambert, Erica Nol, W. John Richardson, Chris Risley and Chip (D. V.) Weseloh. Winnifred Cairns and Ian McLaren generously supplied recent unpublished population estimates of Piping 
Plovers in eastern Canada; and Michael S. W. Bradstreet, Ann Lambert, Gary Miller, Erica Nol and Chris Risley provided information on the status of the Great Lakes population. Herb Copland outlined the extent of the Piping Plover's breeding range in Manitoba.

\section{Irene Reinson and Heather Craig} typed several drafts of the manuscript. The technical support provided by LGL Ltd. - environmental research associates - in assembling this report is greatly appreciated.

\section{Appendix. Notes on Other Species}

While conducting the Piping Plover survey from 19-21 June 1978, we recorded a total of 88 species of birds. Here we have included details on all shorebirds, Sandhill Crane and five colonial nesters; other species are listed below. The observations of migrant shorebirds are of interest since our visit fell within a period when Arctic breeding shorebirds are generally assumed to be absent from southern Saskatchewan.

WHITE PELICAN. On 19 June about 100 pairs were found nesting on a small island in Middle Quill Lake. Nests contained eggs and young to about 1 week old. Pelicans were seen soaring over Big Quill Lake on 20 June (45 in 3 flocks) and 21 June (flock of 25).

DOUBLE-CRESTED CORMORANT. 19 June: 30 pairs nested on the periphery of the pelican colony; 10 nests contained from 2-4 eggs each, the others contained young up to 7 days old. 20 June: 2 flew over the SW corner of Big Quill Lake.

SANDHILL CRANE. 20 June: groups of 2 and 3 individuals along the $S$ shore, and a single crane along the NE shore of Big Quill Lake. All were feeding along mudflats and were apparently non-breeders or failed breeders.

KILLDEER. A total of $150+$ were seen during the 3 days; although several pairs performed distraction displays, no nests or young were seen.

BLACK-BELLIED PLOVER. 19 June: 6 on shoals in Middle Quill Lake. 21 June: a total of 15 scattered along the $E$ shore of Big Quill Lake.

RUDDY TURNSTONE. 19 June: 2 at Middle Quill Lake. 20 June: 24 along the $S$ and SE shores of Big Quill Lake. 21 June: 8 along the $E$ shore of Big Quill Lake.

UPLAND SANDPIPER. 19 June: 1 near the NW shore of Middle Quill Lake. 21 June: 1 near the NE shore of Big Quill Lake.

SPOTTED SANDPIPER. 20 June: a pair on a small rocky pond near the $S$ shore of Big Quill Lake. Apparently absent from the alkaline shore of the lakes.

WILLET. A total of $117+$ adults was seen; two broods noted on 21 June. The largest flock was of 15 on 20 June.

RED KNOT. 19 June: 2 feeding with 3 Black-bellied Plovers and 2 turnstones at Middle Quill Lake.

WHITE-RUMPED SANDPIPER. 20 June: a flock of 10 along the $E$ shore of Big Quill Lake.

BAIRD'S SANDPIPER. 19 June: 5 along the E shore of Big Quill Lake.

STILT SANDPIPER. 20 June: a flock of 15 at Middle Quill Lake.

SEMIPALMATED SANDPIPER. 20 June: a flock of 20. An additional 75 "peeps" seen on 20-21 June may have included this species.

MARBLED GODWIT. A total of $146+$ seen; also 2 broods (each with 1 chick) estimated at 7 days old. The largest group was of 45 with 15 Willets on 20 June.

SANDERLING. A total of 43 seen.

AMERICAN AVOCET. About 200 adults were seen in the area. 19 June: 22 nests with eggs on islands and shoals in Middle Quill Lake; nests contained 1 egg (1 nest), 2 eggs (2), 4 eggs (15), 5 eggs (1), 8 eggs (1), 1 egg +3 chicks (1), and 3 chicks (1). NORTHERN PHALAROPE. A total of 105 seen, mostly along the $S$ shore of Big Quill Lake on 20 June.

CALIFORNIA and RING-BILLED GULLS. The four most northeasterly islands in Middle Quill Lake contained a large breeding population of gulls. Among 
these 4 islands, the NW island was occupied by 450 pairs of Ring-billed and 40 pairs of California Gulls, and the SW island contained $150+$ pairs of California Gulls. The two most easterly of the nesting islands were not visited but at least 1,000 gulls were seen there. Most eggs had hatched by 19 June; chicks were up to 2 weeks old.

COMMON TERN. 19 June: a small island contained 30 nests; most eggs had hatched.

OTHER SPECIES: Horned Grebe, Eared Grebe, Canada Goose, Mallard (nests with 7 and 12 eggs), Gadwall (nests with 9, 10, 12 and 12 eggs), Pintail (nest with 15 eggs), Green-winged Teal, Blue-winged Teal, American Wigeon, Northern Shoveler, Redhead, Canvasback, Lesser Scaup (nests with 8, 10, 11 and 13 eggs), Common Goldeneye, Bufflehead, Ruddy Duck, Red-tailed Hawk, Swainson's Hawk, Marsh Hawk, American Kestrel, Sharp-tailed Grouse, American Coot, Franklin's Gull, Black Tern, Rock Dove, Mourning Dove, Common Flicker, Eastern Kingbird, Alder Flycatcher, Least Flycatcher, Horned lark, Tree Swallow, Bank Swallow, Barn Swallow, Purple Martin, Black-billed Magpie, Common Crow, House Wren, Long-billed Marsh Wren, Gray Catbird, Brown Thrasher, American Robin, Mountain Bluebird, Sprague's Pipit, Cedar Waxwing, Loggerhead Shrike, Starling, Warbling Vireo, Yellow Warbler, Common Yellowthroat, House Sparrow, Bobolink, Western Meadowlark, Yellow-headed Blackbird, Red-winged Blackbird, Northern Oriole, Brewer's Blackbird, Brown-headed Cowbird, American Goldfinch, Savannah Sparrow, Baird's Sparrow, Le Conte's Sparrow, Vesper Sparrow, Clay-colored Sparrow, Song Sparrow, Chestnut-collared Longspur.

1ANWEILER, G. G. 1969. The birds of the Last Mountain Lake Wildlife Area, Saskatchewan. Can. Wildl. Serv. Rept. (Unpubl.).

2AMERICAN ORNITHOLOGISTS' UNION. 1957. Check-list of North American birds. Fifth ed. Am. Orni- thol. Union, Baltimore, Md. 691 pp.

3ARBIB, R. 1972. The blue list for 1973. Am Birds 26:932-933.

${ }^{4}$ ARBIB, R. 1973. The blue list for 1974 . Am. Birds 27:943-945.

5ARBIB, R. 1974. The blue list for 1975. Am. Birds 28:971-974.

6ARBIB, R. 1975. The blue list for 1976. Am. Birds 29:1067-1077.

7 ARBIB, R. 1976. The blue list for 1977. Am. Birds 30:1031-1039.

${ }^{8} \mathrm{ARBIB}, \mathrm{R}$. 1977. The blue list for 1978 . Am. Birds 21:1087-1096.

9BELCHER, M. 1961. The birds of Regina, Saskatchewan. Spec. Publ. No. 3. Saskatchewan Nat. Hist. Soc., Regina. $76 \mathrm{pp}$.

10BENT, A. C. 1907. Summer birds of southwestern Saskatchewan (Part I). Auk 24:407-430.

11 BENT, A. C. 1927. Life histories of North American shore birds. Part II. U.S. Nat. Mus., Bull. No. 146. 412 pp.

12BRADSTREET, M. S. W., G. W. PAGE and W. G. JOHNSTON. 1977. Shorebird migration at Long Point, Lake Erie 1966-1971: seasonal occurrence, habitat preference and variation in abundance. Can. FieldNat. 91:225-236.

${ }^{13}$ CAIRNS, W. E. 1977. Breeding biology and behaviour of the Piping Plover (Charadrius melodus) in southern Nova Scotia. Unpubl. M.Sc. Thesis, Dalhousie Univ., Halifax, Nova Scotia. ${ }^{14}$ CALDWELL, R., R. MacLENNAN, W. HARRIS and H. WOLOWSKY. 1972. An ecological survey of Ranch Lake, Saskatchewan. Can. Wild. Serv./Dep. Nat. Resour. joint report. (Unpubl.).

15CARTAR, R. 1976. The status of the Piping Plover at Long Point, Ontario, 1966-1975. Ont. Field Biol. 30:42-45.

16DEVITT, O. E. 1967. The birds of Simcoe County, Ontario. Brereton Field Naturalists' Club, Barrie, Ontario. 192 pp.

17FERRY, J. 1910. Birds observed in Saskatchewan during the summer of 1909. Auk 27:185-204.

${ }^{18}$ GODFREY, W. E. 1950. Birds of the 
Cypress Hills and Flotten Lake regions, Saskatchewan. Nat. Mus. Can., Bull. No. 120. 96 pp.

19GODFREY, W. E. 1966. The birds of Canada. Nat. Mus. Can., Bull. No. 203, Biol. Ser. No. 73. Queen's Printer, Ottawa. 428 pp.

20GOLLOP, J. B. (ed.). 1966. Saskatoon bird review. Saskatoon Nat. Hist. Soc. 1(4):13 (Mimeo.).

21GOLLOP, J. B. (ed.). 1971. Saskatoon mini-bird review. No. 3. June 1-July 31, 1971. Saskatoon Nat. Hist. Soc. (Mimeo.). 26 pp.

22GOLLOP, M. A., and A. R. SMITH. 1969. Bird notes for the Elbow region, Saskatchewan. Blue Jay 27:80-81.

23GREEN, J. C., and R. B. JANSSEN. 1975. Minnesota birds - where, when and how many. Univ. Minn. Press, Minneapolis. $210 \mathrm{pp}$.

${ }^{24} \mathrm{HATCH}$, D. R. M., and V. LIEFFERS. 1977. The status of the birds of the Qu'Appelle Basin. Wildl. Tech. Rept. 77-2. Sask. Dep. Tourism and Renewable Resour. (Unpubl.).

${ }^{25}$ HOUSTON, C. S. 1949. The birds of the Yorkton district, Saskatchewan. Can. Field-Nat. 63:215-241.

26HUSSELL, D. J. T., and R. D. MONTGOMERIE. 1966. The status of the Piping Plover at Long Point, 1960 1965. Ont. Field Biol. 20:14-16.

27JAMES, R. D., P. L. MCLAREN and J. C. BARLOW. 1976. Annotated checklist of the birds of Ontario. Roy. Ont. Mus., Life Sci., Misc. Publ. 75 pp.

28KONDLA, N. C., and H. W. PINEL. 1973. Breeding records of 19 species of birds in southern Alberta. Blue Jay 31:153-157.

29MACOUN, J., and J. M. MACOUN. 1909. Catalogue of Canadian birds. 2nd ed. Geol. Surv. Branch, Dep. Mines, Ottawa. 761 pp.

30MITCHELL, H. H. 1924. Birds of Saskatchewan. Can. Field-Nat. 38-101-120.

31NERO, R. W. 1963. Birds of the Lake Athabasca region, Saskatchewan. Spec. Publ. No. 5. Saskatchewan Nat. Hist. Soc., Regina. 143 pp.

32PALMER, R. S. 1967. Plumage descrip- tions and species accounts, p. 139267. In: G. D. Stout (ed.). The shorebirds of North America. Viking Press, New York. 270 pp.

33PINKOWSKI, B. C. 1976. Michigan bird survey, summer 1976. Jack-Pine Warbler 54:160-167.

${ }^{34}$ RENAUD, W. E. 1974. Nesting Piping Plover in Saskatchewan. Blue Jay 32: 158-162.

35RENAUD, W. E., and S. J. SHADICK (eds.). 1972. Saskatoon Field Notes. Spring migration (March 16-May 31, 1972). Saskatoon Nat. Hist. Soc. (Mimeo.). 26 pp.

36RUMP, P. C. 1975. Piping Plover nesting at Diefenbaker Lake, Saskatchewan. Blue Jay 33:180.

37SALT, W. R., and J. R. SALT. 1976. The birds of Alberta. Hurtig Publisher, Edmonton, Alberta. 498 pp.

38SKAAR, P. D. 1975. Montana bird distribution. P. D. Skaar, Bozeman, Montana. 56 pp.

39SHEPPARD, R. W. 1935. Mid-summer bird notes from Long Point, Norfolk County, Ontario. Auk 52:196-197.

40SNYDER, L. L. 1931. A faunal investigation of Long Point and vicinity, Norfolk County, Ontario. Trans. Roy. Can. Inst. 18:139-227.

41SOPER, J. D. 1970. Unpublished field notes on the birds observed and collected in the province of Saskatchewan, Canada, in 1914, 1921, 1927 and from July, 1937 to September, 1947. Zool. Dep., Univ. Alberta, Edmonton. (Unpubl.).

42STEWART, R. E. 1975. Breeding birds of North Dakota. Tri-college Centre for Environmental Studies, Fargo, North Dakota. 295 pp.

43TESSE:N, D. D. (ed.). 1977. The nesting season: June 1-July 31, 1977. Western Great Lakes region. Am. Birds 31:1142-1146.

44TODD, IV. E. C. 1947. Notes on the birds of southern Saskatchewan. Ann. Carnegie Mus. 30:383-421.

45VERMEER, K. 1970. Aquatic breeding birds of the Isle of Bays, 1969. Blue Jay 28:86-87. 